\title{
The cultural heritage circulation in a globalized world: Should we build stronger borders or stronger bridges?
}

\author{
Octavian-Dragomir JORA \\ The Bucharest University of Economic Studies, Bucharest, Romania \\ octavian.jora@rei.ase.ro \\ Matei-Alexandru APĂVĂLOAEI \\ The Bucharest University of Economic Studies, Bucharest, Romania \\ matei.apavaloaei@rei.ase.ro \\ Mihaela IACOB \\ The Bucharest University of Economic Studies, Bucharest, Romania \\ mihaela.iacob@fin.ase.ro
}

\begin{abstract}
The scope of this paper is to explore if the free market and its corollaries - private property and the freedom to trade both nationally and internationally - are compatible with the conservation, search and optimal use of heritage goods. Our argument starts from the fact that culture is not a free-floating wraith but a set of tangible and intangible elements that are attributed special spiritual signification by the present generation and that are dependent on scarce material means to be expressed and passed on to our heirs. By taking scarcity as our starting point, we will provide an economic analysis of the implications that follow from the alternative approaches that can be employed to manage heritage goods, namely, a private property order coordinated through prices or a public property form of organisation coordinated through orders and interdictions. After tracing the implications of these two general principles of allocating resources, we will briefly look at how heritage goods are regulated, both on a national and international level, to gain a better understanding of the spirit that permeates the "rules of the game." Finally, we are going to see how the two general principles (market vs command and control) apply to the debate raging between the cosmopolites and the nationalists regarding the international trade in heritage goods. After carefully scrutinising some of the arguments put forward in this dispute over the appropriate means to be used, we conclude that free markets and free trade are the only adequate ways for reaching the objective sought by those on both sides of the debate.
\end{abstract}

Keywords: cultural heritage, property rights, national regulations, international trade.

\section{Introduction}

Popular wisdom and scientific literature devoted to the economics of (tangible) cultural heritage accommodate a "double conceptual dualism": on the one hand, of property vs. heritage (as conceptual approaches concerning the representation of the cultural belongings) and, on the other hand, of humankind's vs. nation's property/heritage (as proper moral/legal jurisdictions where property issues are assessed and addressed). The difference between cultural property and cultural heritage supposedly resides in the fact that the second term rather overrides (or it "should") the first one, as intellectual and spiritual accumulations and achievements of a society are poorly covered by the word "property". Heritage (patrimony) is said to express better the idea of successional transfer among generations, through communitarian and careful protection and preservation, of the "social meanings", which is the very essence of culture; putting it otherwise, the widespread utilitarian logic of (private) property translates, in cultural matters, in reifying and mercantile behaviours. Turning now to the "geo-cultural order", 
cultural property/heritage may be seen either as belonging to humanity (that is to human species) or to nations (that is to particular kinships). These views are said to rather complement each other than being in conflict, despite sensibly different implications in terms of policy.

The present paper explores the rationales for considering cultural products as compatible with the logic of the free market, finding inbuilt compatibility between private (much more than public) property rights (and contractual freedom) and the freedom of cultural expression (also) in the realm of cultural "public goods". Accordingly, the freedom to trade internationally will be analysed in parallel with the idea of cultural exchanges, observing virtuous and vicious circles emerging in the global scenery, where the needs for identity preservation face or fuse with those for diversification of experiences. The paper is organised into four parts. Part I will discuss the problem of culture as tributary (despite elevated, spiritual objectives) to earthly scarcity of resources, whose freedom of disposal affects/defects the culture of a society. Part II will contain a very brief inventory of the most common provisions that are associated with the public regulation - i.e., the regime of ownership - of artistic, cultural heritage goods. Part III will recollect some figures relevant to the problem of worldwide mobility of the cultural heritage assets, sketching an image of the recent years' economic geography of cultures. Part IV will reveal arguments from cultural nationalists asking for heritage protectionism (export bans), explaining that they fail to achieve increases in the cultural welfare and wealth of nations.

\section{Property in cultural expression: markets or hierarchies Property rights}

Cultural heritage is defined, by the United Nations' specialized agency devoted to the promotion of international collaboration through educational, scientific, and cultural reforms, as "the legacy of physical artefacts and intangible attributes of a group or society that are inherited from past generations, maintained in the present and bestowed for the benefit of future generations" (UNESCO). The cultural heritage of any human society plays a crucial role for its members; it allows them to gain a sense of identity by adhering to a set of shared values and by accepting a common historical interpretation of the past. Common identity helps individuals better tackle uncertainty and potential conflicts by simply taking recourse to this common ground: cultural heritage. In this sense, cultural heritage enters in fecund resonance with the universal/civilizational institution of property/ownership, mainly in the tangible "artefactual" dimension.

\section{Economic systems}

Property rights provide an orderly response to the problems scarcity poses to society, helping the latter in minimising conflictuality and maximising cooperation, minimising waste and maximising wealth. Naturally, societies do not function solely on the basis of "atomistic" private property rights, being perfectly compatible with commonly owned resources. Individuals must adopt viable rules and accept legitimate leaders to play a role in administering the co-owned resources. But, here, one must clearly distinguish between (private) governance and (mere) government. The first form of organisation is characterised by voluntarily accepted rules and social elites that emerge from the bottom up, while the latter is based on coercion, expropriation and hierarchical edicts that are imposed top down on a community (Hoppe, 2001). The domain of cultural heritage management cannot escape these basic social caveats and choices. 


\section{Culture(s)}

In the cultural sphere, property rights also serve as a disciplinary device, given the fact that even if cultural artefacts embed "commonly shared values", they are primarily part of every individual's own, intimate valuation "schemes". Individual preferences are demonstrated in action (in "culture", as in any social expression); the concatenations of individual preferences are realised in markets, based on property rights. The success or the failure of certain cultural expressions is a function of spiritual, symbolical vibration as it is one of the price-signalled availability of scarce material, tangible resources. Still, regardless of whether we agree (or we are happy) with letting cultural life at the mercy of mundane forces, this is a fact; market value and cultural value can be educated to converge. Voluntary validation of cultural artefacts is more in the spirit of a free society, assessed either nationally or globally (Cowen, 2000; Cantor, 2012).

Under a free market/laissez-faire/capitalist order, the prevailing tendency is toward greater output and a greater variety of cultural products (the intrinsic moral and aesthetic quality of which remain a highly debatable issue). Free market tends to send to the dustbin of history the works not enough beloved by the general public or not in the graces of the patrons of arts, as it also tends to improve critical wisdom. Taking these judgments as benchmark, the impact of state interventionism can be assessed beyond the narrative that "official elites" can eradicate a Ruskin-type "cultural market failure". Tastes cannot be improved forcefully (not even by employing milder means, as supposed by funding "fine culture" by tax revenues); moreover, the state may (and historically it did) act as a deterrent for artistic criticism. Besides suspicions on statecorrupted cultural guilds, "unintended consequences" of good intentions can be seen.

\section{Regulating the cultural heritage: in and between nations Cultural heritage laws within nations}

The first significant piece of legislation is considered the decree of Pope Pius II (1464) prohibiting the removal from the Vatican of works of art. Seven decades later, Pope Paul III set up the "Antiquities Commissariat", the first public institution of this kind in history. The Renaissance brought with it an expansion of the interest and means of preserving the past works of art in the private collections of the Italian nobility, acting for their custodians as an indicium nobilitatis and testimonies of their ancestry roots in the Roman age. In the XVII and XIX centuries, the European aristocracy and bourgeoisie set themselves culturally in the new world geography: if the great discoveries had brought only barbarity, the memory of the old Mediterranean cradle (Egyptian, Greek, Roman) was a needed spiritual anchor for the European civilization.

In the XIX century, the "great age of amateur archaeologists" began, and along with it the trade of antiquities, whose outlets were museums, universities, commercial and political elites, with a particular concentration in Paris and London. Napoleonic France, then Wilhelminian Germany exceled in institutions dedicated to the protection of heritage, amid the imperialist-nationalistic composite accents, specific to the statutes of great powers. But young nations were also taking action in this respect. The Romanian principalities responded to this trend: in 1860, the Commission for Historical and Archaeological Research was established, empowered to research and record cultural and artistic assets; in 1892, in full process of national (cultural) modernisation, Romania passed the "Law for the preservation of public monuments".

In the second half of the XX century, the international market for cultural goods was experiencing an unprecedented development, beyond the narrow circle of public museums and wealthy private collectors and connoisseurs. On a cyclical world economic 
background, with significant fluctuations in the value of traditional movable and immovable assets, cultural goods began to be sought as quite suitable investments to better store "economic value". All the segments of this cultural artefacts market are now booming: the "white" segment (the official one, of the big auction houses), the "black" segment (of the first hand "smugglers") and the "grey" segment (of the intermediaries). The present global siege upon global cultural heritage is thought to be a function of greed and power as of institutional ill-design or mal-enforcement.

The contemporary cultural heritage law, embodied by domestic legislation as well as international agreements, expanded in response to the risk of transforming objects of heritage into a smuggled commodity to the detriment of, ultimately, their preservation and thus possibility of being cherished by the peoples of the world. Nowadays, UNESCO framework dominates the cultural heritage international law, addressing issues of protection, cooperation, rectification, criminal justice and dispute resolution, complemented by the fundamental law of international trade (the "WTO Agreement"), which accommodates in its non-discriminative rhetoric a discriminatory treatment for "national cultural treasuries" (Nafziger and Paterson, 2014).

\section{Cultural heritage laws across nations}

Merryman (1986) notes that although both the 1954 Hague Convention for the Protection of Cultural Property in the Event of Armed Conflict and the 1970 UNESCO Convention on the Means of Prohibiting and Preventing the Illicit Import, Export and Transfer of Ownership of Cultural Property aim to protect the cultural property/heritage, each of them attaches to the term "protection" different meanings, embodying different and somewhat dissonant sets of values. The distinction lies in the particularity of the objectives of each of the two documents: one dealing with the protection of cultural assets by the actions of the belligerent parties in times of military conflict, and the other with the illicit trafficking of heritage goods. But the difference seems to be more profound than the one coming from the specificity of the objectives, reflecting fundamental differences in the philosophy of cultural justification, with effects in the format of international regulations targeting cultural heritage.

For example, the preamble to the 1954 Hague Convention speaks of the cultural heritage of mankind. The 1970 UNESCO Convention, in its preamble, but also in the rest of the document, emphasises the interest of states in the national cultural heritage. The 1954 Hague Convention seeks to protect cultural property from deterioration or destruction. The 1970 UNESCO Convention strives for the nations' custody over cultural property. The two accents - one cosmopolitan, another nationalist; one for protection, the other for preservation - characterise the two major ways of thinking of cultural property. As such, one can speak of "cultural internationalism" as opposed to "cultural nationalism" (the latter being the dominant view). In many cases, the two approaches support each other, but they can also go in divergent ways. The distinction cultural nationalism - cultural internationalism becomes significant when denouncing "destructive retention" or "greedy neglect".

Nationalism and cultural internationalism also differ in their responses to the practice of storing cultural objects and facilitating access to them. Many artefacts of ancient civilizations are retained by some states, on their national territory, although these cultures are abundantly present in both public museums and private collections. Such surplus of artefacts is just stored without sometimes even being catalogued, inventoried and made available to the public and to the researchers either from that country or from abroad. Museums in other states that lack such works would be willing 
to acquire, study and expose them, while also preserving them. Foreign dealers and collectors would also be happy to buy them and extend circulation. Cultural nationalism translates into the bulk storage of unused artefacts, despite that there is a global "market" from which all parties ("interested", not "idle", collectors, researchers, and visitors) may therefore benefit.

Cultural internationalism recommends that cultural objects be made available worldwide by sales, exchanges or rentals. The achievements of ancient cultures in the countries of origin could be exposed to a broader audience, responding to the interest of foreigners to see and study such works (part of mankind's cultural heritage) and partially meeting the demand (which otherwise is covered by the illicit market) through open and legal exchange of cultural property. It is suspected that many countries of origin retain duplicates of cultural artefacts beyond any imaginable need, refusing to make them available to foreign museums, collectors, dealers; by banning exports, no use is made of what is retained, losing also positive spill-overs. A country is wealthy not necessarily in the obsolete mercantilist way, by "storing" value within its borders, but by putting it to wider circulation, thus ensuring its replenishing. "Cultural popularity" is an intangible production factor.

\section{Civilization as cultural diversity: on ex/changing values Between "metrics" of cultural heritage trade}

Modern and contemporary world of nation-states has found another raison d'État in "cultural security". Questioning its importance is considered an offence, as it is also the case with the traditional territory raptures. As said, the states are divided, with respect to cultural artefacts circulation, into origin-states for cultural goods and outlet-states (with transit-states as intermediate). The dialectic replicates the classical economic "producer-merchant-consumer" chain: in origin-countries, the supply exceeds the demand, whereas in outlet-countries, the case is reversed, and the principle of communicating vessels is doing its job inexorably, moving them from the first category to the second. Egypt, Greece, India or Mexico are exporters for the enjoyment of "Western capitalist aristocrats" (located in countries such as Switzerland, France, Germany, Japan, the Scandinavian states, United Kingdom and United States of America) and for the Persian Gulf "petro-sheiks" or "novi ruski" oligarchs.

For national accounts representations, the (un)balances of cultural trade can be calculated, but they can only emphasise the elementary intuition, as well as inflame the nationalist spirits. The question of protectionism is being raised - an inverted protectionism, blocking trade at the expeditor, not at the recipient. While other forms of export are frenetically encouraged, the cultural one upturns dialectic. Domestic laws prohibit or limit exports of goods from the "national cultural heritage", and international agreements reinforce the vigilance, few nations being lax in this respect (for example, the US and Switzerland, this precisely due to their net positive cultural trade balance). The reasons of cultural protectionism (Ginsburgh \& Mairesse, 2013) range from the "romantic Byronism" of getting back home the identity effigies, to political uses of the cultural heritage symbolism, to the lack of expertise and management regarding the exploitation of this valuable resource, to vested interests towards prohibition, for huge rents can be extracted from cultural looting.

The international flow of cultural heritage goods is regulated by a number of selfstanding treatise and international conventions, but also by special provisions that amend the general rules that apply to most other goods (Nafziger and Paterson, 2014). For instance, according to WTO rules, the "General Exceptions" stipulated in Article XX 
of the GATT exempt cultural goods from the interdiction of applying any prohibition to the export or import of goods - the so-called "National Treasuries" clause. The exemption reads as follows: "Subject to the requirement that such measures are not applied in a manner which would constitute a means of arbitrary or unjustifiable discrimination between countries where the same conditions prevail, or a disguised restriction on international trade, nothing in this Agreement shall be construed to prevent the adoption or enforcement by any contracting party of measures:... (f) imposed for the protection of national treasures of artistic, historic or archaeological value". But the cultural commerce is part of the dialogue of nations.

Table 1. Top 10 exporters of heritage goods \& rest of the world, USD, 2016

\begin{tabular}{llrr} 
No. & Country & $\mathbf{2 0 1 6}$ & Share \\
\hline 1 & United Kingdom & $1,364,511,471$ & $36 \%$ \\
2 & USA & $899,047,709$ & $24 \%$ \\
3 & France & $312,981,349$ & $8 \%$ \\
4 & China, Hong Kong & $292,588,657$ & $8 \%$ \\
5 & Switzerland & $272,330,494$ & $7 \%$ \\
6 & Germany & $183,161,585$ & $5 \%$ \\
7 & Austria & $81,465,146$ & $2 \%$ \\
8 & Saudi Arabia & $43,686,988$ & $1 \%$ \\
9 & Belgium & $35,796,139$ & $1 \%$ \\
10 & Canada & $33,466,373$ & $1 \%$ \\
11 & Rest of the World $\quad$ Share of Top 10 & $250,350,182$ & $7 \%$ \\
& & & $\mathbf{9 3 \%}$ \\
\hline
\end{tabular}

Table 2. Top 10 importers of heritage goods \& rest of the world, USD, 2016

\begin{tabular}{llrr} 
No. & Country & $\mathbf{2 0 1 6}$ & Share \\
\hline 1 & USA & $1,699,436,845$ & $33 \%$ \\
2 & United Kingdom & $1,159,832,725$ & $22 \%$ \\
3 & China, Hong Kong & $834,969,269$ & $16 \%$ \\
4 & Switzerland & $294,617,007$ & $6 \%$ \\
5 & Netherlands & $268,770,942$ & $5 \%$ \\
6 & France & $179,962,333$ & $3 \%$ \\
7 & Germany & $172,182,138$ & $3 \%$ \\
8 & Japan & $79,995,062$ & $2 \%$ \\
9 & Austria & $55,061,557$ & $1 \%$ \\
10 & China & $40,917,766$ & $1 \%$ \\
11 & Rest of the World & $404,745,241$ & $8 \%$ \\
& $\quad$ Share of Top 10 & $\mathbf{9 2 \%}$ \\
\hline
\end{tabular}

Source: UN Comtrade.

Historically viewed, the heritage goods market has been very concentrated, the Top 10 importers and exporters (mostly the same) making up more than $90 \%$ of the entire value of transactions. This contributes to a more accurate image that defies hasty intuitions about (underdeveloped) countries systematically depleted of their treasuries to the benefit of (developed) others. When looking at the 2016 situation for each nation (Figure 1), we can see that there is no correlation between income per capita and the country's position as a net importer or net exporter of heritage goods. We can observe that the countries that have an approach closer to the free market stance when it comes to the international flow of heritage goods are located to the right of the graph, meaning that they have high volumes of both exports and imports, while countries that have a more inward-looking policy are situated closer to the Oy axis. 


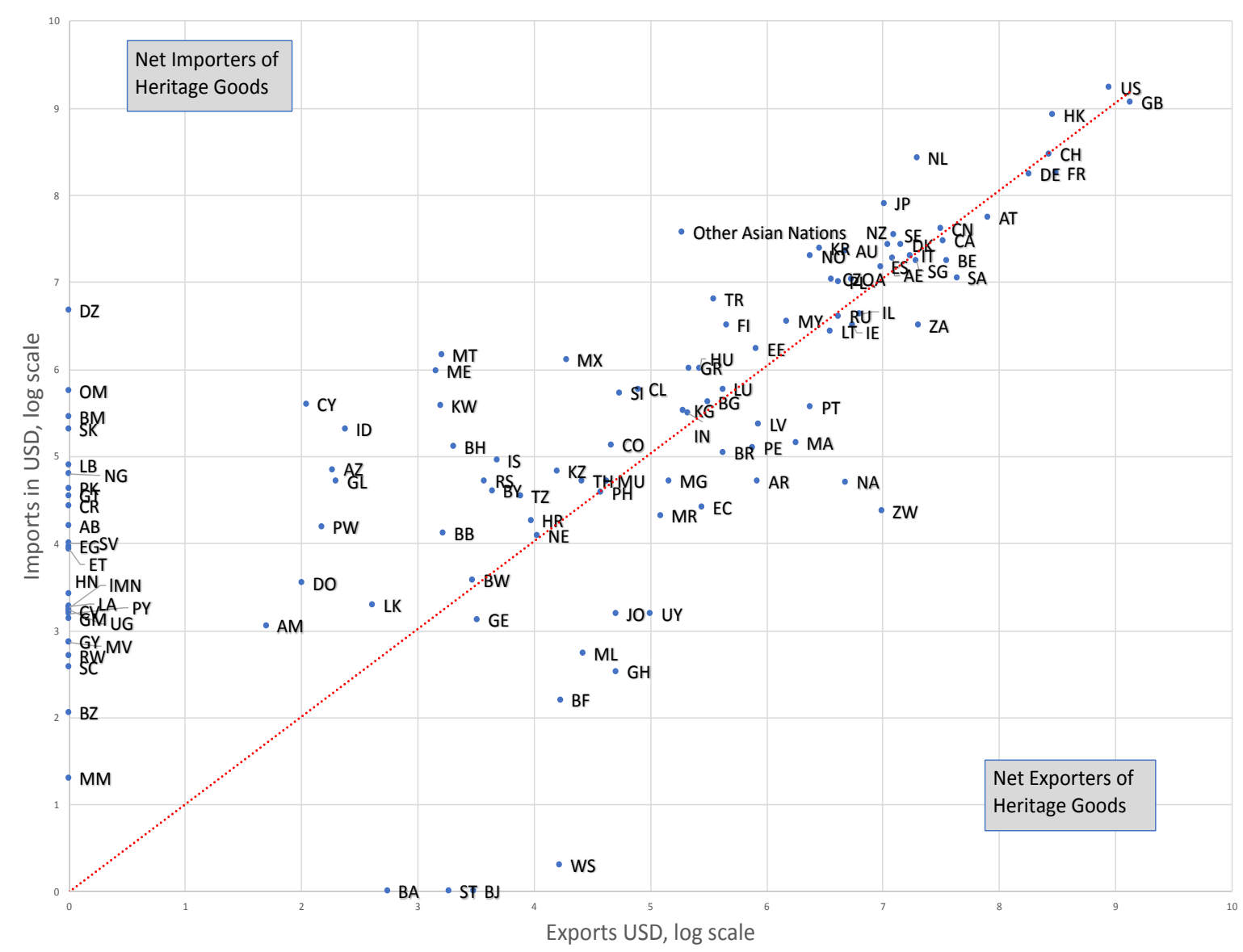

PICBE $\mid 1075$

Figure 1. Heritage goods imports \& exports, by country

(117 countries, 2016, USD, log scale)

Source: UN Comtrade.

\section{"Metaphors" of cultural heritage trade}

The dilemma of cultural heritage belonging to the international context is illustrated by the classic example of the Parthenon marble sculptures currently in the possession of the British Museum and the sculptured bust of the Egyptian queen Nefertiti at the Neues Museum in Berlin. Of universal value, these works of art are owned by states other than those in whose territory they were created, which seems to defy the usual logic of things for militants of art conservation on the territory of its birth. Still, in accordance with the principle of "universality of arts", it must transcend the debates on the "property rights" (of one country or another) and come to the possession of the most effective actor possible, able of popularizing it, thus making it useful/available for as many people as possible. Therefore, from an utilitarian view, the heritage looks like literary translation (Ginsburgh and Mairesse, 2013: 153): a written work in a certain country becomes known or even consecrated in other countries by being translated and transferred, thus getting in the possession of others. Why not allowing the legal "translation" of cultural heritage?

The great debate over extended access versus relative isolation of cultures between legal borders remains open and various compromises are proposed. In the specific literature, there are at least five "alternatives" for both the commercialisation and the repatriation of cultural heritage artefacts: (1) copies; (2) digitisation; (3) 
lending; (4) sharing; (5) restrictions to export. The copies allow to widespread art and, thus, to educate a larger audience that has access to it: the "Lascaux II" cave example is cited as relevant; Marcel Duchamp and Andy Warhol challenged the traditionalist paradigm saying that the reputation of a work is given precisely by the extent to which it is copied; plus, anyway, the restoration lays between originals and copies. Digital collections have the advantages of storage space and accessibility, and lending and sharing across countries are viable art transfer options. As such, the disputed marble sculptures of the Parthenon and Nefertiti's bust could be considered (cynically for some tastes) not "raptures", but "borrowings" from Greece and Egypt, respectively, to the UK and Germany.

\section{Viewing (un-)fairness in the freedom of trading heritage Cultural freedom of trade and the balance argument}

One argument coming from cultural nationalists in favour of limiting free trade of cultural heritage goods says that the free trade of others lasts only insofar their balances look well (they have "good" deficits, importing and retaining more cultural assets than exporting). To this "hypocritical freedom", the response would be pre-emptive protectionism. But this reasoning misses the point that such a policy shift does not hurt only the potential future foreign buyers of heritage goods. The burden produced by a prohibition of this sort is going to disproportionately fall upon those domestic individuals that have accumulated a stock of heritage goods (as investment), and that may want to sell it in the future. It is the affluent citizens of those protectionist countries that will feel the brunt of such measures. However, the adoption of such an opportunistic policy is not going to be as easy as presumed, as insights provided by "the logic of collective action" (Olson, 2002) indicate. According to this approach, a small number of individuals that suffer the concentrated costs of a political policy can efficiently organise to block the enactment of this legislation. A small body of art collectors has the upper hand in setting an effective lobby action when compared with the efforts of various "loose" cultural stake-holders. Export bans hamper the chance of other countries to repatriate their historical national goods on voluntary/purchase basis, thus spurring international animosities. Not to mention the impetus to black markets that destroy transparency of and accessibility to heritage assets.

\section{Cultural freedom of trade and the poverty argument}

The argument of "cultural infancy" as a reason for "trade openness" adopted by certain countries also misses the target. On the one hand, this argument ignores the fact that countries with relatively few indigenous artefacts may still have a (merchantable) stock of accumulated foreign artefacts. On the other hand, such a critique does not take into consideration another aspect: the ultimate relativity and subjectivity of (cultural) values. It is true that the US does not have as many or as imposing ancient artefacts originated on the North American continent, but this does not mean that it lacks heritage goods dating from its so vibrant XVIII century. For instance, the writing desk of a "Founding Father" may be worth more than an ancient Phoenician statue. Also, the very fact that some countries have a relatively "shorter history" means that the number of available artefacts is lower, so they are scarcer, and therefore they may command a relatively higher price. Perhaps such countries do not have artefacts from a certain period, or they have a less plentiful stock of such goods that they can sell, but precisely because of this the few heritage goods they do possess command higher prices. More importantly, it is those countries that allegedly do have only a "short history" that are in danger of losing 
the few cultural heritage items they store within their borders, while the fact that the cultural panic is still absent from the public discourse may be because they endorse a less rigid and more vivid vision on how a culture is made from the interplay of worldwide cultures.

\section{Legalizing trade, as an anti-smuggling measure}

The way of acquiring heritage assets is of major concern, as the accreditation of illegal/unlawful means can blow up cultural relations between nations. The works are often obtained in an illicit manner, obviously also due to legal barriers in the way of their free circulation. Illegal excavations of unprotected sites or illegal transactions with works of art occur despite measures to combat these phenomena, with the effect of "barbarizing" the exploitation of cultural goods. One of the solutions to enhance responsibility are the public-private partnerships, flourished in the 1970s and 1980s and relying on services provided by private enterprises, in a transparent legal framework erected and enforced by the governmental authorities. China approached such a way to recover antiques of the China Sea. Thus, the retrieved objects were then sold, attracting the responsible interest of collectors and antiquarians.

Another solution is for museums to get rid of some of the surplus artefacts, which collect dust in dark storages instead of being accessible elsewhere to the public. The available solutions are: transfer, lending, controlled destruction or definitive sale of excess objects from museums. The advantages would be the following: (a) first of all, art becomes more popular and is better used, reaching the beneficiaries who value it most; (b) secondly, the sale of museum works can help reduce sales on the black market and consolidate an organized and legitimate artefacts market, since any collector prefers to purchase objects from safe sources with a higher probability of authenticity; (c) last but not least, the artwork circuit may involve the existence of several owners, who can direct their collections to other museums and exhibiting centres, which bid for them following the preferences of their public.

\section{Art's migratory vs. cultures' sedentary customs}

Nowadays, art has become very mobile, both public and private collections being exhibited in various locations around the world. Ginsburgh and Mairesse 2013 (160-1) cite few examples: in 2008, 50 paintings and sketches signed by Van Gogh arrived at the Albertina Museum in Vienna, while Tutankhamun was shown in London. States from different hemispheres do cooperate - i.e., Iran and the UK, China and Italy.

In the epicentre of these artistic migrations there are, in most cases, material interests, too. The size of fundraising is important in the logic of these collaborations. For example, the Orsay Museum sent its exhibits to Japan and the Gulf States to raise money, and the Kunsthistoriches Museum in Vienna was granted500,000 euros to lend the work of Vermeer, The Art of Painting, for the Metropolitan Museum Art in Tokyo.

Museum branches are created in different states: i.e., the Louvre Museum has accepted to include in its brand a spectacular museum opened in Abu Dhabi, part of a complex geo-cultural, geo-economic and geo-political deal. Also, we are witnessing the internationalisation of the museums' boards: i.e., the Trustees Board of the Russian State Museum from St. Petersburg gathers specialists from France and Scotland.

The mobility of art raises vibrant emotions, although the asymmetry against "common" movements remains visible: for instance, the director of the Uffizi Gallery contested the disposition to lend Tokyo a painting of Titian, Venus of Urbino, considered 
as indissolubly linked to Italian spiritual territory, while, one former director of the Guggenheim Foundation encouraged even the "full migration" of museums.

\section{Conclusions}

In this paper, we suggest that, if governments aspire to stand a better chance of repatriating the heritage goods that have been exported to other countries, the best policy to follow is one of free trade. Prohibitions can only push the international flow of heritage goods in the black market, and at the same time raise the price of those heritage goods that have already reached foreign territories. By encouraging free trade, the scarcity of these goods will be reduced. This will tend to lower prices as well as eliminate speculative stockpiling of heritage goods by foreign collectors. As a result, governments that seek to repatriate heritage goods will be in a better position to bid for those artefacts that they deem to be of the utmost importance and that have already left the country. Even if such a policy will result in fewer objects being concentrated in a given country, at least it would increase the chance of repatriating, on a voluntary, market basis those artefacts that are acknowledged as most valuable to each nation's heritage.

We have also looked at the composition, volume and geographic direction of the trade flow in heritage/cultural goods. We saw that more liberal countries account for more significant volumes of both imports and exports. Also, we saw that less developed countries and middle-income countries account for only a tiny part of international trade flows in heritage goods and consequently are not faced with an imminent drain of such artefacts. We also remarked that heritage goods represent only a small category of the more encompassing concept of trade in cultural goods. If one does not fixate exclusively on heritage goods but on cultural goods in general, then free trade is again the answer. Additionally, one must not ignore that some of the now traded cultural goods will become, with the passing of time, heritage goods in their own right. A more plentiful supply of present cultural goods means more fully-fledged heritage goods in the future, this is to the benefit of the cultural communities of our civilisation.

\section{References}

Cantor. P.A. (2012). The Invisible Hand in Popular Culture: Liberty vs. Authority in American Film and TV. Lexington, KY: The University of Kentucky.

Cowen, T. (2000). In Praise of Commercial Culture. Cambridge, MA: Harvard University Press.

Da Milano, C. (2008). Volunteering for cultural heritage in Europe. In Da Milano, C., Gibbs K. \& Sani, M. (Eds.). Volunteers for Cultural Heritage: A European Handbook (pp. 9-22). Ljubljana: Slovene Museum Association.

Gibson, K. (2009). Profit from the priceless: heritage sites, property rights and the duty to preserve. Business and Society Review, 114(3) (Fall 2009), 327-348.

Ginsburgh, V. \& Mairesse, F. (2013). Issues in the international market for cultural heritage. In Rizzo, I. \& Mignosa, A. (Eds.). Handbook on the Economics of Cultural Heritage (pp. 151-170). Cheltenham, UK, Northampton, MA, USA: Edward Elgar.

Hoppe, H.H. (2001). Democracy: The God That Failed. New Brunswick, NJ: Transaction Publishers.

Jora, O.D. (2016). Spiritualitate, materialitate și proprietate. Cultura mea, cultura ta, cultura noastră, cultura lor [Spirituality, materiality and property. My culture, your culture, our culture, their culture]. București: Editura ASE. 
Lazăr, A. (2007). Metodologia investigării infracțiunilor contra patrimoniului cultural national [Methodology of investigation for crimes against national cultural heritage]. Revista Drept - Series Jurisprudentia, 10, 191-206.

Luca, S.A. (1999). Arheologia generală (prima parte) [General Archaeology (first part)]. Alba Iulia: Editura Altip.

Merryman, J.H. (1986). Two Ways of Thinking About Cultural Property. The American Journal of International Law, 80(4) (Oct. 1986), 831-853.

PICBE $\mid 1079$

Mises, L. von. ([1949] 1998). Human Action. A Treatise on Economics (the scholars' edition). Auburn, AL: Ludwig von Mises Institute.

Nafziger, J.A.R. \& Paterson, R.K. (2014). International Trade in Cultural Material. In Nafziger, J.A.R and Paterson, R.K. (Eds.). Handbook on the Law of Cultural Heritage and International trade (pp. 19-44). Cheltenham, UK: Edward Elgar.

Olson, M. (2002). The Logic of Collective Action, Public Goods and the Theory of Groups. Cambridge, MA: Harvard University Press.

Ponzini, D. (2010). The Process of Privatization of Cultural Heritage and the Arts in Italy: Analysis and Perspectives. International Journal of Heritage Studies, 16(6) (Oct. 11 2010), 508-521.

Rojas, E. (2001). Revitalization of Historic Cities with Private Sector Involvement: Lessons from Latin America. In Serageldin, I., Shluger, E. \& Martin-Brown, J. (Eds.). Historic Cities and Sacred Sites: Cultural Roots and Urban Futures (pp. 391-400). Washington DC: The World Bank.

Rothbard, M.N. ([1982] 1998). Ethics of Liberty. New York, NY: New York University Press.

Seaman, B.A. (2013). The Role of the Private Sector in Cultural Heritage. In Rizzo, I. \& Mignosa, A. (Eds.). Handbook on the Economics of Cultural Heritage (pp. 111128). Cheltenham, UK, Northampton, MA, USA: Edward Elgar.

*** Convention for the Protection of Cultural Property in the Event of Armed Conflict, The Hague. (14 May 1954). http://portal.unesco.org/en/ev.php-

URL_ID=13637\&URL_DO=DO_TOPIC\&URL_SECTION=201.html [Accessed: 31.10.2017].

*** http://www.worldbank.org/ [Accessed: 31.10.2017].

*** https://comtrade.un.org/ [Accessed: 31.10.2017].

*** The 2009 UNESCO Framework for Cultural Statistics (FCS). (2009). UNESCO Institute for Statistics. http://unesdoc.unesco.org/images/0019/001910/191061e.pdf [Accessed: 31.10.2017].

*** UNESCO Convention on the Means of Prohibiting and Preventing the Illicit Import, Export and Transfer of Ownership of Cultural Property, Paris. (14 November 1970). http://portal.unesco.org/en/ev.phpURL_ID=13039\&URL_DO=DO_TOPIC\&URL_SECTION=201.html [Accessed: 31.10.2017]. 